\title{
IS THE RELATIONSHIP BETWEEN POPULATION DENSITY AND BODY SIZE CONSISTENT ACROSS INDEPENDENT STUDIES? A META-ANALYTICAL APPROACH
}

\author{
BINI, L. M. ${ }^{1,2}$ COELHO, A. S. G. ${ }^{1,3}$ and DINIZ-FILHO, J. A. F. ${ }^{1}$ \\ ${ }^{1}$ Departamento de Biologia Geral, ICB, UFG, C.P. 131, CEP 74001-970, Goiânia, GO, Brazil \\ ${ }^{2}$ Programa de Pós-graduação em Ecologia de Ambientes Aquáticos Continentais, Nupélia, UEM \\ ${ }^{3}$ Programa de Pós-graduação em Genética e Melhoramento de Plantas, ESALQ, USP \\ Correspondence to: Luis Mauricio Bini, Departamento de Biologia Geral, ICB, UFG, C.P. 131, CEP 74001-970, \\ Goiânia, GO, Brazil, e-mail: bini@icb1.ufg.br \\ Received February 25, 1999 - Accepted March 15, 2000 - Distributed February 28, 2001
}

(With 1 figure)

\begin{abstract}
The Energetic Equivalence Rule (EER) is a controversial issue in ecology. This rule states that the amount of energy that each species uses per unit of area is independent of its body size. Here, we perform a meta-analytical procedure to combine and compare the slopes of population density and body size relationships across independent studies of mammals and birds. We then compared a distribution of 50,000 bootstrap combined slopes with the expected slope $(b=-0.75)$ under the EER. The combined slopes obtained for mammals and birds separately were -0.755 and -0.321 , respectively. The homogeneity hypothesis (i. e. within studies the slopes differ by no more than would be expected due sampling variation) was rejected in both cases. So, EER cannot be supported since the use of an exponent of -0.75 is, in fact, an oversimplification. Significant heterogeneity of slopes within each group (mammals and birds) is an indicator of inferential problems related with variation in body size, spatial scale, the regression model adopted and phylogenetic relationships among species. So, we consider that questions regarding the estimation and validity of slopes is the next challenge of density-body size relationship studies.
\end{abstract}

Key words: meta-analysis, energetic equivalence rule, mammals, birds.

\section{RESUMO}

A relação entre densidade populacional e tamanho do corpo é consistente entre estudos independentes? Uma abordagem meta-analítica

A regra de equivalência energética (Energetic Equivalence Rule, EER) é um assunto controverso em Ecologia. Essa regra prediz que a quantidade de energia que cada espécie usa por unidade de área é independente de seu tamanho corpóreo. Neste trabalho foi realizada uma meta-análise com o objetivo de combinar os coeficientes angulares de regressões densidade/tamanho do corpo em estudos independentes realizados em mamíferos e aves. Esses estudos foram comparados com o coeficiente esperado pela EER $(b=-0,75)$ utilizando 50.000 valores obtidos por meio da técnica de bootstrap. Os coeficientes combinados para mamíferos e aves foram iguais a $-0,755$ e $-0,321$, respectivamente. A hipótese de homogeneidade desses coeficientes, ou seja, dentro de cada grupo taxonômico os coeficientes variam apenas ao acaso devido a erros de amostragens, foi rejeitada. Desse modo, a adoção da EER é de fato uma simplificação não justificada devido à heterogeneidade existente, que implica problemas de estimativa nos coeficientes em função de variação na amplitude do tamanho do corpo, escala espacial utilizada para estimar a densidade, modelo de regressão utilizado e relações filogenéticas entre as espécies. Assim, a questão para os próximos estudos na relação densidade/tamanho do corpo é, ainda, a própria validade de estimativa dessa relação e não a maneira de combinar os coeficientes de modo 
a testar uma hipótese ecológica geral, que poderia ser resolvida utilizando os procedimentos metaanalíticos.

Palavras-chave: meta-análises, regra de equivalência energética, mamíferos, aves.

\section{INTRODUCTION}

Several studies have recently discussed the relationship between population density (D) and body size (W) and its implications for the validity of the so called Energetic Equivalence Rule (EER) (Damuth, 1981; Lawton, 1989; Blackburn et al., 1990; Marquet et al., 1990; Currie, 1993; Ebenman et al., 1995; Blackburn \& Gaston, 1997). The EER states that the amount of energy that each species uses per unit of area is independent of its body size. This is a consequence of estimating an empirical slope of -0.75 for the relationship between $\mathrm{D}$ and $\mathrm{W}$, and a slope of 0.75 for the relationship between individual metabolic requirement and W. So, combining the two allometric equations results in a zero exponent of population energy use (PEU) in relation to body size. One important criticism of this rule is that the algebraic procedures used ignore the variation of slopes across studies (Marquet et al., 1995). However, most studies compare these independent studies using a "vote counting" approach throughout the inspection of a large table of b's (slopes), a's (intercepts) and their significance levels. In other words, the estimated slopes between D and $\mathrm{W}$ or between individual metabolic requirements $(\mathrm{M})$ and $\mathrm{W}$ are compared only by eye. Unfortunately, they fail to recognize that the variation among studies, even in the signal of the allometric relationships, can be accounted for by different sample sizes. However, this problem can be solved by using metaanalytical procedures (Hedges \& Olkin, 1985), only recently applied to ecological data (Gurevitch et al., 1992; Werf, 1992; Fernandez-Duque \& Valeggia, 1994; Arnqvist \& Wooster, 1995; FernandezDuque, 1997).

Blackburn \& Gaston (1997) recently summarized the results from more than 500 studies relating population density to body size, for different animal groups, using complex ANOVA designs to evaluate the effects of data type (compilations versus sample studies), spatial scale (local versus regional), density measure (crude and ecological densities), body size range (range in variation of independent variable) and dimensionality of assemblages (animals use environment in two or three dimensions), on the estimated regression slopes. They rejected EER and concluded that a large portion of the variance among slopes can be accounted for by the data type and spatial scale at which density is obtained. However, the ANOVA used by these authors are strongly unbalanced and probably affected by heterocedasticity.

Here, we evaluate if the exponent of -0.75 associated with body size can be used as a valid parameter to derive the relative population energy use according to the EER. We employed a metaanalytical procedure to combine the slopes of the relationship between $\mathrm{D}$ and $\mathrm{W}$ applied to previously published data on mammals and birds.

\section{MATERIAL AND METHODS}

For this analysis, we used 74 published slopes of the relationship between $\mathrm{D}$ and $\mathrm{W}$ for mammals and 53 slopes for birds (Damuth, 1981, 1993; Peters, 1983; Brown \& Maurer, 1987; Carrascal \& Tellería, 1991; Nee et al., 1991; Blackburn et al., 1993; Ebenman et al., 1995; Silva et al., 1997).

Based on the original approach delineated by Hedges \& Olkin (1985) for performing a metaanalysis combining results from different experiments (control versus experimental groups), we established a new procedure for combining regression slopes. The combined angular coefficient (b ) for each group (mammals and birds) can be expressed as a weighted average of slopes, given by

$$
\mathrm{b}_{\mathrm{c}}=\sum_{\mathrm{i}=1}^{\mathrm{k}} \mathrm{w}_{\mathrm{i}} \mathrm{b}_{\mathrm{i}} / \sum_{\mathrm{i}=1}^{\mathrm{k}} \mathrm{w}_{\mathrm{i}}
$$

Where $\mathrm{k}$ is the number of studies, $\mathrm{b}_{\mathrm{i}}$ is the slope of the ith study and $w$ are weights. These weights are the simple reciprocals of the slope variances.

The meta-analytical procedure used here needs that one knows the slope, its standard error 
and the sample sizes for each study. In some of the studies used here (e. g. Brown \& Maurer, 1986; Damuth, 1993), only slopes, type I error and sample size were available, and in this case the standard error was derived using the mathematical association among these parameters.

The variance of combined slope $b_{c}$ is given by

$$
\mathrm{S}_{\mathrm{b}_{\mathrm{c}}}^{2}=1 / \sum_{\mathrm{i}=1}^{\mathrm{k}} \mathrm{w}_{\mathrm{i}}
$$

It may be also advantageous to use a bootstrap procedure to obtain the confidence intervals for the combined slope (Gurevitch, 1996; Fernandez-Duque, 1997). We used 50,000 bootstrap replicates to estimate combined slopes for birds and mammals data sets.

We also employed the homogeneity statistic $\mathrm{Q}_{\mathrm{w}}$ to test the critical null hypothesis that slopes are homogeneous within each data set (mammals and birds), versus the alternative hypothesis that at least one differs from the rest. This test is critical due to the need of combining several different studies (within groups) to achieve a general parameter that could be used to describe all of them (and, in this specific case, to validate EER). This statistic is given by

$\mathrm{Q}_{\mathrm{w}}=\sum_{\mathrm{i}=1}^{\mathrm{k}} \mathrm{w}_{\mathrm{i}} \mathrm{b}_{\mathrm{i}}^{2}-\frac{\left(\sum_{\mathrm{i}=1}^{\mathrm{k}} \mathrm{w}_{\mathrm{i}} \mathrm{b}_{\mathrm{i}}\right)^{2}}{\sum_{\mathrm{i}=1}^{\mathrm{k}} \mathrm{w}_{\mathrm{i}}}$

This statistics follows a $\chi^{2}$ distribution with k-1 degrees of freedom.

\section{RESULTS AND DISCUSSION}

The combined slope across all studies (mammals plus birds) was estimated as -0.65 , with a variance of 0.00007 . These general results invalidate the statement about EER as a general rule of community structure (Damuth, 1981). In other words, since D scales with $\mathrm{W}$ as $\mathrm{D} \alpha \mathrm{W}^{-0.65}$ (significantly greater than -0.75 ) and if we assume that individual metabolic requirements (M) still scale

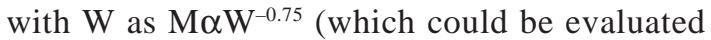

by performing another meta-analysis) the exponents of $\mathrm{W}$ no longer cancel each other. So, PEU can be dependent on $\mathrm{W}$ if an unbiased general estimate is employed, and if this combined slope of -0.65 is assumed as a valid simplification of slopes (partially supporting the empirical analysis of Marquet et al., 1995) (but see the $\mathrm{Q}_{\mathrm{w}}$ statistics below). The lower exponent can be explained if we consider that some individual studies estimated slopes by using simple linear relationships when, in fact, triangular envelope relationships exist (Brown \& Maurer, 1987). This divergence between these two types of models was recently discussed by Marquet et al. (1995).

The combined slopes obtained for mammals and birds separately were -0.755 and -0.321 , respectively. As expected, these two values are significantly less than zero $(\mathrm{p}<0.05)$.

In the case of mammals, the confidence intervals (both assuming normal distribution of slopes and obtained by bootstrap) clearly overlap the parametric value of -0.75 and, in fact, the mean of bootstrapped combined slope is very close to the parameter assumed by EER. So, at least for this group, sample sizes alone do not produce a bias in combined slope. Also, if we assume that variance in body size is at least partially correlated with sample size, the arguments of Lawton (1989) and Blackburn et al. (1990) for rejecting EER based on a restricted variance of body size in some studies would no longer be valid for mammals. Damuth (1993) gave indirect support for this statement by finding no correlation between slope and range of body size.

So, in principle, EER seems to be valid for mammals (but see statistics $\mathrm{Q}_{\mathrm{W}}$ presented below). For birds, however, the EER cannot be supported by a simple combined slope. Silva et al. (1997) also suggested that a restricted amplitude of body size can explain differences between the two groups. Standard overlap analysis of confidence intervals showed that the effect of $\mathrm{W}$ on $\mathrm{D}$ was significantly larger for mammals.

The confidence intervals of the combined slope are also slightly different for each group, using standard technique (based on normal distribution) and bootstrap, especially for birds (Table 1 ). The distribution of the 50,000 bootstrapped estimates (Fig. 1) also suggests a bimodal pattern of combined slopes in birds. 

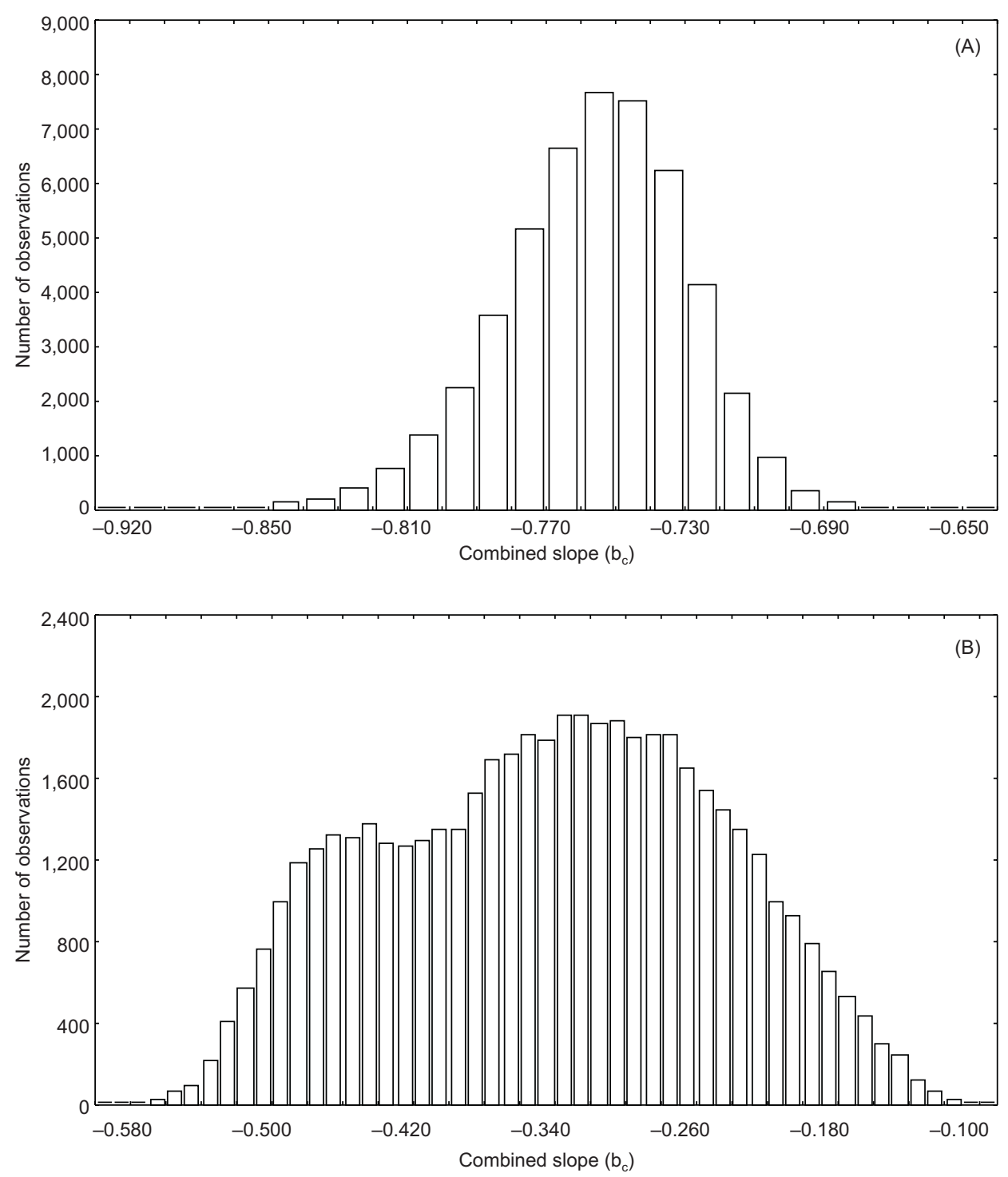

Fig. 1 - Distribution of 50,000 bootstrap combined slopes $\left(b_{c}\right)$ for mammals (A) and birds (B).

This bimodal distribution that emerged from bootstrap procedure can be associated with recent claims and data by Ebenman et al. (1995) and Silva et al. (1997), indicating differences in slopes between flying and flightless birds or between birds with different dietary categories, especially carnivorous birds. However, we were not able to find out the exact factor generating the bimodal distribution without the original information (species level data) used to compute slopes for most studies. We suggest that a meta-analytical approach is necessary to per- form an explicit statistical test of this pattern in the future. When compared to standard $\chi^{2}$ table with $\mathrm{k}-1$ degrees of freedom, the values of $\mathrm{Q}_{\mathrm{w}}$ obtained indicate that the variation among studies within the two taxonomic groups cannot be attributed to sampling error alone (Table $1, \mathrm{p}<0.001$ ). The high variation among studies indicates that the use of an empirical exponent (i. e., - 0.75 ) is in fact an oversimplification, even for mammals, as has been stated by many authors (Blackburn et al., 1993; Marquet et al., 1995 and references therein). 
TABLE 1

Results of meta-analysis of the population density-body size relationship for mammals and birds, including the combined slopes $\left(b_{c}\right)$, variance, homogeneity statistics $\left(Q_{w i}\right)$, and confidence interval using standard normal distribution and bootstrap.

\begin{tabular}{|c|c|c|c|c|c|}
\hline & $\mathbf{b}_{\mathbf{c}}$ & $\mathrm{S}_{\mathrm{b}_{\mathrm{c}}}^{2}$ & $\mathbf{Q} \mathbf{w}_{\mathbf{i}}$ & $95 \%$ confidence limits & $\begin{array}{c}95 \% \text { confidence limits } \\
\text { (bootstrap) }\end{array}$ \\
\hline Mammals & -0.7547 & 0.0000945 & $278.13(\mathrm{df}=73)$ & lower $=-0.774$ & lower $=-0.815$ \\
\hline$(\mathrm{n}=74)$ & & $0.000732 *$ & & upper $=-0.735$ & upper $=-0.707$ \\
\hline Birds & -0.3207 & 0.000295 & $251.51(\mathrm{df}=52)$ & lower $=-0.354$ & lower $=-0.502$ \\
\hline$(\mathrm{n}=53)$ & & $0.008918 *$ & & upper $=-0.287$ & upper $=-0.161$ \\
\hline
\end{tabular}

* Variance obtained by bootstrap.

By considering the results of meta-analysis applied to the relationship between $\mathrm{D}$ and $\mathrm{W}$, it is possible to overcome the initial problem of combining slopes from different studies. We showed that, for mammals, although the estimated slope of -0.75 is not dependent on differences in sample size (which could support EER, as stated by Damuth, 1981), there is a significant heterogeneity among different studies. So, even for mammals, this meta-analysis indicates that EER is an oversimplification and that the original algebraic procedure used by Damuth (1981) is not valid. For birds, EER is clearly not supported.

It is very important to note that the meta-analytical approach adopted here obviously does not solve other problems associated with the estimation of slopes themselves, including the question of constraint envelopes (Brown, 1995; Marquet et al., 1995), dependence of slope in relation to variation in body size (Damuth, 1993; Arneberg et al., 1998), spatial scale (Blackburn \& Gaston, 1996; Cyr et al., 1997), the regression model to be adopted (Blackburn \& Gaston, 1998) and the use of phylogenetic based statistical analysis (Arneberg et al., 1998). In fact, the significant heterogeneity of slopes within each group detected by $Q_{w}$ statistics is indicative of these problems, confirming the conclusions of Blackburn \& Gaston (1997). Nevertheless, this study permits a shift from questions related to combining different studies to questions regarded to the own estimation and validity of slopes.

\section{REFERENCES}

ARNEBERG, P., SKORPING, A. \& READ, A. F., 1998, Parasitic abundance, body size, life histories and the energetic equivalence rule. Am. Nat., 151: 497-513.

ARNQVIST, G. \& WOOSTER, D., 1995, Meta-analysis: synthesizing research findings in ecology and evolution. Tree, 10: 236-240.

BLACKBURN, T. M. \& GASTON, K. J., 1996, Abundancebody size relationship: the area you census tell you more. Oikos, 75: 303-309.

BLACKBURN, T. M. \& GASTON, K. J., 1997, A critical assessment of the form of the interspecific relationship between abundance and body size in animals. Journal of Animal Ecology, 66: 233-249.

BLACKBURN, T. M. \& GASTON, K. J., 1998, Some methodological issues in macroecology. Am. Nat., 151: 6883.

BLACKBURN, T. M., BROWN, V. K., DOUBE, B. M., GREENWOOD, J. J. D., LAWTON, J. H. \& STORK, N. E., 1993, The relationship between abundance and body size in natural animal assemblages. J. Anim. Ecol., 62: 519-528.

BLACKBURN, T. M., HARVEY, P. H. \& PAGEL, M. D., 1990, Species number, population density and body size relationships in natural communities. J. Anim. Ecol., 59: 335-345.

BROWN, J. H., 1995, Macroecology. Univ. of Chicago Press, Chicago, 269p.

BROWN, J. H. \& MAURER, B. A., 1986, Body size, ecological dominance and Cope's rule. Nature, 324: 248250 . 
BROWN, J. H. \& MAURER, B. A., 1987, Evolution of species assemblages: effects of energetic constraints and species dynamics on the diversification of North American avifauna. Am. Nat., 130: 1-17.

CARRASCAL, L. M. \& TELLERÍA, J. L., 1991, Bird size and density: a regional approach. Am. Nat., 138: 777-784.

CURRIE, D. J., 1993, What shape is the relationship between body size and population density. Oikos, 66: 353-358

CYR, H., DOWNING, J. A. \& PETERS, R. H., 1997, Density-body size relationships in local aquatic communities. Oikos, 79: 333-346.

DAMUTH, J., 1981, Population density and body size in mammals. Nature, 290: 699-700.

DAMUTH, J., 1993, Cope's rule, the Island rule and the scaling of mammalian population density. Nature, 365 : 748-750.

EBENMAN, B., HEDENSTRÖM, A., WENNERGREN, U., EKSTAM, B., LANDIN, J. \& TYRBERG, T., 1995, The relationship between population density and body size: the role of extinction and mobility. Oikos, 73: 225-230.

FERNANDEZ-DUQUE, E., 1997, Comparing and combining data across studies: alternatives to significance testing. Oikos, 79: 616-618

FERNANDEZ-DUQUE, E. \& VALEGGIA, C., 1994, Metaanalysis: a valuable tool in conservation research. Conserv. Biol., 8: 555-561.

GUREVITCH, J., 1996, News developments in ecological meta-analysis. Bull. Ecol. Soc. Am. Suppl., 77(3): 176.
GUREVITCH, J., MORROW, L. L., WALLACE, A. \& WALSH, J. S., 1992, A meta-analysis of competition in field experiments. Am. Nat., 140: 539-572.

HEDGES, L. V. \& OLKIN, I., 1985, Statistical methods for meta-analysis. Academic Press, San Diego, 369p.

LAWTON, J. H., 1989, What is the relationship between population density and body size? Oikos, 55: 429-434.

MARQUET, P. A., NAVARRETE, S. A. \& CASTILLA, J. C., 1990, Scaling population density to body size in rocky intertidal communities. Science, 250: 1.125-1.127.

MARQUET, P. A., NAVARRETE, S. A. \& CASTILLA, J. C., 1995, Body size, population density and energetic equivalence rule. J. Anim. Ecol., 64: 325-332.

NEE, S., READ, A. F., GREENWOOD, J. J. D. \& HARVEY, P. H., 1991, The relationship between abundance and body size in British birds. Nature, 351: 312-313.

PETERS, R. H., 1983, The ecological implications of body size. Cambridge Univ. Press, Cambridge, 329p.

SILVA, M., BROWN, J. H. \& DOWNING, J. A., 1997, Differences in population density and energy use between birds and mammals: a macroecological perspective. $J$. Anim. Ecol., 66: 327-340.

WERF, E. V., 1992, Lack's clutch size hypothesis: an examination of evidence using meta-analysis. Ecology, 73: 1.699-1.705. 